\title{
Disseminating FBT to a private practice setting: practicalities and pitfalls
}

\author{
Mandy Goldstein*, Christopher E Thornton \\ From 2015 ANZAED Conference: Riding the Waves to Recovery \\ Surfers Paradise, Australia. 21-22 August 2015
}

The use of effective treatments for eating disorders has been emphasised, given their well-known risks. Despite this, the research-practice gap persists. The Redleaf Practice recently undertook an evaluation to explore the effectiveness of family-based treatment (FBT) for adolescent anorexia nervosa in a private practice setting. The study, while supporting the use of FBT in private practice, raised questions about barriers to the uptake of this treatment in this setting. This paper will therefore present an exploration of these challenges, and will offer practical recommendations to those considering the use of FBT in alternate treatment settings.

Published: 23 November 2015

doi:10.1186/2050-2974-3-S1-040

Cite this article as: Goldstein and Thornton: Disseminating FBT to a

private practice setting: practicalities and pitfalls. Journal of Eating

Disorders 2015 3(Suppl 1):040.

* Correspondence: mandy.goldstein@theredleafpractice.com

Submit your next manuscript to BioMed Central and take full advantage of:

- Convenient online submission

- Thorough peer review

- No space constraints or color figure charges

- Immediate publication on acceptance

- Inclusion in PubMed, CAS, Scopus and Google Scholar

- Research which is freely available for redistribution 